\title{
THE POTENTIAL USE OF PROBIOTIC STRAINS LACTOBACILLUS ACIDOPHILUS NRRL B 4495, BIFIDOBACTERIUM BIFIDUM NRRL B41410 IN “LOR WHEY CHEESE" AND THE EFFECTS ON SENSORY PROPERTIES ${ }^{*}$
}

\author{
Reyhan Irkin ${ }^{1 \bowtie}$, Onur Yalcin ${ }^{2}$ \\ ${ }^{1}$ Food Engineering Department, Engineering Faculty, Balikesir University \\ TR10145, Balikesir, Turkey \\ ${ }^{2}$ Biology Department, Art-Science Faculty, Balikesir University \\ TR10145, Balikesir, Turkey
}

\begin{abstract}
Background. In recent years, probiotic bacteria have increasingly been incorporated into various foods as dietary adjuncts. The viability of the probiotic bacteria Lactobacillus acidophilus NRRL B 4495 and Bifidobacterium bifidum NRRL B41410 in salted (1\% w/w) and unsalted lor whey cheese during storage (21 days) at a refrigerated temperature $\left(4^{\circ} \mathrm{C}\right)$ was evaluated.

Material and methods. As well as the survival of the probiotic bacteria, total mesophilic bacteria, total lactic acid bacteria, Pseudomonas spp., yeast-mould counts and sensory characteristics were examined in the lor samples.

Results. The Bf. bifidum remained in large numbers, at 7.30 and $7.11 \log \mathrm{cfu} / \mathrm{g}$, and Lb. acidophilus also survived well, with counts of 7.60 and $7.47 \mathrm{log} \mathrm{cfu} / \mathrm{g}$, for unsalted and salted cheeses respectively. Salted lor cheeses with added $L b$. acidophilus have the highest sensory scores in the groups.

Conclusion. "Lor" whey cheese showed good probiotic properties.
\end{abstract}

Keywords: functional cheese, cheese microbiology, lactic acid bacteria

\section{INTRODUCTION}

"Lor" cheese, produced from whey, is very important in the dairy industry in Turkey. Particularly popular with children, it has a soft texture, and a fat-free version is also available. Lor cheese contains essential amino acids but has a relatively short shelf life (Ciftcioglu et al., 2008; Irkin, 2011). Whey cheese has some advantages over other foods in terms of delivery of viable probiotics, because of its relatively high $\mathrm{pH}$, fat content and mechanical consistency, coupled with a typically low oxygen level. Due to its unripened nature, whey cheese has to be kept refrigerated, and its typically short shelf life contributes to making

\footnotetext{
*This research presents the results of Mr Yalcin's Master of Science thesis. The authors would like to thank Balikesir University Project Unit (BAP2016/117) for supplying this research as well as TEK-SÜT Milk Products Industrial Company (Gonen-Balikesir) for supporting "lor cheese" productions.
} 
lor a particularly suitable carrier for probiotic bacteria (Plessas et al., 2012).

Functional food products are a new category of food products that are marketed as having health benefits. A food can be regarded as functional if it is satisfactorily demonstrated to beneficially affect one or more target functions in the body (Krystallis et al., 2008; Urala and Lahteenmaki, 2007).

The main science-based benefits related to probiotics are: antimicrobial activity, anticarcinogenic properties, beneficial effects on mineral metabolism (especially regarding bone stability), attenuation of symptoms of bowel disease, reduction of food allergy symptoms, and reduction of LDL-cholesterol levels (Granato et al., 2010; Ishibashi and Yamazaki, 2001; Kun et al., 2008; Nagpal et al., 2014).

Adequate numbers of viable cells, namely the 'therapeutic minimum', need to be consumed regularly for probiotics to have an effect on consumers (Hattingh et al., 2001).

Previous studies have demonstrated that the addition of probiotic bacteria to the various cheese varieties in recent years (Freitas et al., 2014; Tamime et al., 2005). However, there is a lack of information on lor with added probiotic bacteria, and under salted conditions.

Consequently, the objectives of this study were to:

1. Determine the growth of two probiotic strains (Lactobacillus acidophilus NRRL B 4495 and Bifidobacterium bifidum NRRL B41410) in salted and unsalted "lor" whey cheese and determine which probiotic strain exhibits a preference for lor cheese, for the development of a functional cheese.
2. Research the effects of salted or unsalted conditions on the growth of selected probiotic microorganisms, total mesophilic bacteria, total lactic acid bacteria, Pseudomonas spp., yeast-mould counts and sensory analysis over the 21 days of lor shelf life, at $4^{\circ} \mathrm{C}$ under vacuum-packed conditions.

\section{MATERIALS AND METHODS}

\section{Lor production}

Lor cheese was produced in TEK-SÜT Milk Products Company (Gonen, Balikesir). Whey from Kashar cheese production was heated to $50-55^{\circ} \mathrm{C}$. Fat was separated from the whey and then heated to $80^{\circ} \mathrm{C}$ in a boiler tank with $2 \%(\mathrm{w} / \mathrm{v})$ added salt. Lor cheese coagulum began to accumulate on the surface of the whey, and the temperature was increased to $90-95^{\circ} \mathrm{C}$. Lor cheese coagulum was collected from the surface into cloths and drained for $12 \mathrm{~h}$ at $25^{\circ} \mathrm{C}$. Then, the collected mass of lor was divided into six parts; bacterial cultures and/or salt were added and mixed into the different samples (Table 1). Each sample (200 g) was vacuum-packed and stored at $4^{\circ} \mathrm{C}$ for 21 days. The samples were subjected to analyses directly after production and after 1, 4, 7, 14 and 21 days of storage.

\section{Preparation of probiotic cultures}

Freeze-dried probiotic cultures of Bifidobacterium bifidum NRRL B41410 and Lactobacillus acidophilus NRRL B 4495 were obtained from the US Department of Agricultural Research Service, and the probiotic cultures were activated in Liver Infusion Broth (Difco, 226920) at $37^{\circ} \mathrm{C}$ for 3 days before use. Activated

Table 1. Lor sample groups in the research

\begin{tabular}{lc}
\hline \multicolumn{1}{c}{ Sample groups } & Trial names \\
\hline Whey cheese (control) unsalted & CW1 \\
Whey cheese (control) $1 \%(\mathrm{w} / \mathrm{w})$ salted & CW2 \\
Whey cheese (Lactobacillus acidophilus NRRL B 4495 added) unsalted & LA1 \\
Whey cheese (Lactobacillus acidophilus NRRL B 4495 added) $1 \%(\mathrm{w} / \mathrm{w})$ salted & LA2 \\
Whey cheese (Bifidobacterium bifidum NRRL B41410 added) unsalted & BF1 \\
Whey cheese (Bifidobacterium bifidum NRRL B41410 added) $1 \%(\mathrm{w} / \mathrm{w})$ salted & BF2 \\
\hline
\end{tabular}


Irkin, R., Yalcin, O. (2017). The potential use of probiotic strains Lactobacillus acidophilus NRRL B 4495, Bifidobacterium bifidum NRRL B41410 in "Lor Whey Cheese" and the effects on sensory properties. Acta Sci. Pol. Technol. Aliment., 16(2), 181-189. http:// dx.doi.org/10.17306/J.AFS.2017.0493

microorganism cultures $(7.2-7.6 \mathrm{log} \mathrm{cfu} / \mathrm{ml}$ viable cells) were then inoculated into sterilised skimmedmilk media, incubated for about $4 \mathrm{~h}$ at $37^{\circ} \mathrm{C}$ and then mixed into the lor samples $\left(\sim 10^{8} \mathrm{kob} / \mathrm{g}\right.$ lor $)$.

\section{Microbial analysis of lor samples}

Ten grams of each lor sample were diluted with $90 \mathrm{ml}$ of $0.1 \%$ sterile buffered peptone water and tenfold serial dilutions were then prepared in $9 \mathrm{ml}$ of $0.1 \%$ sterile peptone water.

Counts of Bf. bifidum NRRL B41410 were enumerated on Reinforced Clostridial Agar (RCA) with $0.03 \mathrm{~g} / 100 \mathrm{~mL}$ aniline blue and dicloxacillin $(2 \mathrm{mg} / \mathrm{mL}$, Sigma). Plates were incubated under anaerobic conditions at $37^{\circ} \mathrm{C}$ for $48 \mathrm{~h}$ (Kailasapathy et al., 2008).

Numbers of Lb. acidophilus NRRL B 4495 were determined on MRS (deMann, Rogosa and Sharpe, Merck 1.05463) with D-sorbitol ( $10 \mathrm{~g} / 100 \mathrm{~mL})$ media at $37^{\circ} \mathrm{C}$ for $72 \mathrm{~h}$ (Tharmaraj and Shah, 2003).

Total lactic acid bacteria counts were determined using double-layer de Man Rogosa Sharpe agar (MRS Merck 1.10660) under anaerobic conditions after incubation at $30^{\circ} \mathrm{C}$ for $72 \mathrm{~h}$ (Whitley et al., 2000).

Mesophilic microorganisms were determined on plate count agar (PCA, Merck 1.05463) using the pour plate method and incubated at $31^{\circ} \mathrm{C}$ for $72 \mathrm{~h}$ (Gonzales-Fandos et al., 2000).

Pseudomonas spp. were counted on Pseudomonas agar (PA, Merck 1.05284) with CFC supplement at $25^{\circ}$ for $48 \mathrm{~h}$ (ISO 13720, 2000).

Yeasts and moulds were enumerated on yeast extract glucose chloramphenicol agar (YGC, Merck 1.037500500) plates using the surface plate method and incubated at $25^{\circ} \mathrm{C}$ for 5-7 days (Gonzales-Fandos et al., 2000).

All count data were written as logarithms (log $\mathrm{cfu} / \mathrm{g}$ ) prior to statistical analysis. The results were analysed statistically as described in the next section.

\section{Physico-chemical analysis}

The $\mathrm{pH}$ of the whey and lor samples was measured using a pH meter (Hanna HI221 Microprocessor, Hanna Instruments Inc., Woonsocket, Rhode-Island) which was previously calibrated with $\mathrm{pH} 7.0$ and 4.0 standard buffers, on each sampling day. The moisture, fat and salt contents were determined according to AOAC (1995) procedures. The protein content of the samples was determined using Dumas Nitrogen Analyzor (Velp NDA 701) equipment. All analyses were carried out in duplicate at $20^{\circ} \mathrm{C}$.

\section{Sensory analysis}

Analyses of the sensory characteristics of the samples were carried out according to IDF (1995) standards on each day of sampling. A panel, composed of 5 experienced members of our university community, was used to evaluate the whey cheeses for external appearance (colour), flavour, taste and texture with a point scale from 0 to $5(0-$ spoiled sample and unfit for human consumption; 5 - very good). LA1, LA2, BF1, BF2 whey cheese samples were compared with control lor cheese groups.

\section{Statistical analysis}

SPSS 19.0 software for windows (SPSS Inc., Chicago, Illinois, USA) was used for the statistical analyses. A one-way analysis of variance (ANOVA) test was performed to determine mean differences between the lor groups. The level of significance between means was determined by the Tukey HSD and LSD tests.

\section{RESULTS AND DISCUSSION}

\section{Composition and acidity of whey and lor samples}

Proximate analysis of lor samples produced from whey showed average levels of dry matter to be 5.32 $\pm 0.4 \%$, protein $2.3 \pm 0.2 \%$, and fat $1.1 \pm 0.5 \%(\mathrm{~g} / 100 \mathrm{~g}$ moisture). Mean values of $\mathrm{pH}$ were $6.1 \pm 0.9$.

Before the addition of the bacterial cultures, the composition of the lor cheeses was determined: average values of dry matter $28.94 \pm 2.1 \%$ (unsalted lor), $29.3 \pm 1.8 \%$ (salted lor), fat $5.5 \pm 1.3 \%$ (salted and unsalted lor samples), salt content $0.343 \pm 0.5$ (unsalted lor), $1.1 \pm 0.8 \%$ (salted lor), and protein $11.56 \pm 0.8$ (salted and unsalted lor; $\mathrm{g} / 100 \mathrm{~g}$ moisture) were found.

The $\mathrm{pH}$ values of lor samples during the storage period are shown in Table 2. Acid production in control lor samples was lower than the other groups and there were significant differences $(p<0.05)$ in $\mathrm{pH}$ values between the control and other trials. Compared to the control groups, the addition of probiotic cultures influenced the $\mathrm{pH}$ of the samples. Among the samples, the highest drop in $\mathrm{pH}$ value was observed for BF1 
Irkin, R., Yalcin, O. (2017). The potential use of probiotic strains Lactobacillus acidophilus NRRL B 4495, Bifidobacterium bifidum NRRL B41410 in "Lor Whey Cheese" and the effects on sensory properties. Acta Sci. Pol. Technol. Aliment., 16(2), 181-189. http:// dx.doi.org/10.17306/J.AFS.2017.0493

Table 2. Changes of the $\mathrm{pH}$ and sensory scores of lor samples during cold storage $(n=6)$

\begin{tabular}{|c|c|c|c|c|c|c|}
\hline Day & CW1 & CW2 & LA1 & LA2 & $\mathrm{BF} 1$ & $\mathrm{BF} 2$ \\
\hline & \multicolumn{6}{|c|}{$\mathrm{pH}$} \\
\hline 1 & $6.17 \pm 0.2^{\mathrm{a}}$ & $6.06 \pm 0.3^{\mathrm{a}}$ & $5.64 \pm 1.1^{\mathrm{b}}$ & $5.73 \pm 0.9^{b}$ & $5.69 \pm 0.2^{b}$ & $5.75 \pm 0.7^{b}$ \\
\hline 4 & $6.26 \pm 0.4^{\mathrm{a}}$ & $6.04 \pm 0.6^{\mathrm{a}}$ & $5.56 \pm 0.7^{\mathrm{b}}$ & $5.64 \pm 1.0^{\mathrm{b}}$ & $5.67 \pm 0.7^{\mathrm{b}}$ & $5.73 \pm 0.6^{b}$ \\
\hline 7 & $6.17 \pm 1.3^{\mathrm{a}}$ & $6.06 \pm 0.8^{\mathrm{a}}$ & $5.60 \pm 0.4^{\mathrm{b}}$ & $5.71 \pm 0.7^{\mathrm{b}}$ & $5.44 \pm 0.6^{\mathrm{c}}$ & $5.34 \pm 1.1^{\mathrm{c}}$ \\
\hline 14 & $6.07 \pm 0.7^{\mathrm{a}}$ & $6.05 \pm 0.2^{\mathrm{a}}$ & $5.41 \pm 1.8^{\mathrm{b}}$ & $5.59 \pm 0.3^{\mathrm{b}}$ & $4.88 \pm 0.5^{\mathrm{c}}$ & $4.88 \pm 0.2^{\mathrm{c}}$ \\
\hline \multirow[t]{2}{*}{21} & $6.07 \pm 0.6^{\mathrm{a}}$ & $6.06 \pm 0.3^{\mathrm{a}}$ & $5.41 \pm 1.2^{\mathrm{b}}$ & $5.56 \pm 0.5^{\mathrm{b}}$ & $4.86 \pm 0.4^{\mathrm{c}}$ & $4.94 \pm 0.8^{\mathrm{c}}$ \\
\hline & \multicolumn{6}{|c|}{ Sensory evaluations (overall acceptability scores) } \\
\hline 1 & $5.00 \pm 0.0^{\mathrm{a}}$ & $5.00 \pm 0.0^{\mathrm{a}}$ & $4.26 \pm 0.9^{b}$ & $5.00 \pm 0.0^{\mathrm{a}}$ & $3.40 \pm 0.3^{\mathrm{c}}$ & $4.03 \pm 0.6^{b}$ \\
\hline 4 & $4.46 \pm 0.8^{\mathrm{a}}$ & $4.63 \pm 0.5^{\mathrm{a}}$ & $4.06 \pm 0.2^{b}$ & $5.00 \pm 0.0^{\mathrm{c}}$ & $3.30 \pm 0.2^{\mathrm{d}}$ & $3.76 \pm 0.4^{\mathrm{d}}$ \\
\hline 7 & $4.26 \pm 0.7^{\mathrm{a}}$ & $4.83 \pm 0.6^{\mathrm{b}}$ & $4.36 \pm 0.4^{\mathrm{b}}$ & $5.00 \pm 0.0^{\mathrm{b}}$ & $3.96 \pm 0.3^{\mathrm{a}}$ & $4.10 \pm 0.2^{\mathrm{a}}$ \\
\hline 14 & $1.00 \pm 0.0^{\mathrm{a}}$ & $1.00 \pm 0.0^{\mathrm{a}}$ & $3.73 \pm 0.1^{\mathrm{b}}$ & $5.00 \pm 0.0^{\mathrm{c}}$ & $3.20 \pm 0.2^{\mathrm{d}}$ & $3.30 \pm 0.5^{\mathrm{d}}$ \\
\hline 21 & $1.00 \pm 0.0^{\mathrm{a}}$ & $1.00 \pm 0.0^{\mathrm{a}}$ & $3.30 \pm 0.8^{\mathrm{b}}$ & $4.33 \pm 0.4^{\mathrm{c}}$ & $2.96 \pm 0.5^{\mathrm{d}}$ & $3.26 \pm 0.3^{b}$ \\
\hline
\end{tabular}

Means \pm SD within each row not sharing the same lowercase letter are statistically different $(p<0.05)$.

CW1 - lor cheese (control) unsalted, CW2 - lor cheese (control) 1\% (w/w) salted, LA1 - lor cheese (Lactobacillus acidophilus NRRL B 4495 added) unsalted, LA2 - lor cheese (Lactobacillus acidophilus NRRL B 4495 added) 1\% (w/w) salted, BF1 lor cheese (Bifidobacterium bifidum NRRL B41410 added) unsalted, BF2 - lor cheese (Bifidobacterium bifidum NRRL B41410 added) $1 \%$.

and BF2. After 7 days, there were significant differences $(p<0.05)$ in $\mathrm{pH}$ values for all lor samples except CW2. However, there were not any significant differences between the salted and unsalted lor samples for each of the trial groups.

\section{Viability of microorganisms in trial groups}

The viability of $L b$. acidophilus NRRL B 4495 in lor cheeses at $4{ }^{\circ} \mathrm{C}$ during storage is shown in Figure 1a. The maximum cell population of Lb. acidophilus NRRL B 4495 occurred on day 14 as $7.86 \log \mathrm{cfu} / \mathrm{g}$ and then decreased to $7.48 \mathrm{log} \mathrm{cfu} / \mathrm{g}$ in salted lor samples. Subsequently, LA1 and LA2 samples showed similar trends, with all increasing in numbers and reaching a maximum on days 4 and 14 respectively and then declining by a small amount. No significant differences were detected between populations of $L b$. acidophilus found in LA1 and LA2, except on the $4^{\text {th }}$ day $(p>0.05)$.

Figure $1 \mathrm{~b}$ shows the variations in Bf. bifidum numbers in the lor groups. The highest viable numbers were in the BF1 samples on day 14. No significant differences between the viable numbers of BF1 and BF2 samples were found $(p>0.05)$, except on day 4 and 14 of storage $(p<0.05)$.

On the first day, the total viable numbers of the samples CW1 and CW2 were shown to be statistically different from the other groups ( $p<0.05$; Fig. 1c). It was thought that total viable numbers were affected by probiotic cultures that were present in the samples $\mathrm{BF}$ and LA from the beginning. The samples BF2 exhibited a significantly greater reduction than the other groups after 4 days' storage $(p<0.05)$. On day 21 , all the samples were $<5 \log \mathrm{cfu} / \mathrm{g}$, except CW1 and CW2. The highest total viable count was obtained from the CW1 lor sample, followed by CW2, BF1, LA1, LA2 and finally BF2, at the end of storage.

During storage, the average number of viable lactic acid bacteria increased rapidly and significantly $(p<$ 0.05) in BF1 and BF2 samples (Fig. 1d). The highest lactic acid bacteria counts were determined for BF1 samples. Regarding total lactic acid bacteria, 
Irkin, R., Yalcin, O. (2017). The potential use of probiotic strains Lactobacillus acidophilus NRRL B 4495, Bifidobacterium bifidum NRRL B41410 in "Lor Whey Cheese" and the effects on sensory properties. Acta Sci. Pol. Technol. Aliment., 16(2), 181-189. http:// dx.doi.org/10.17306/J.AFS.2017.0493
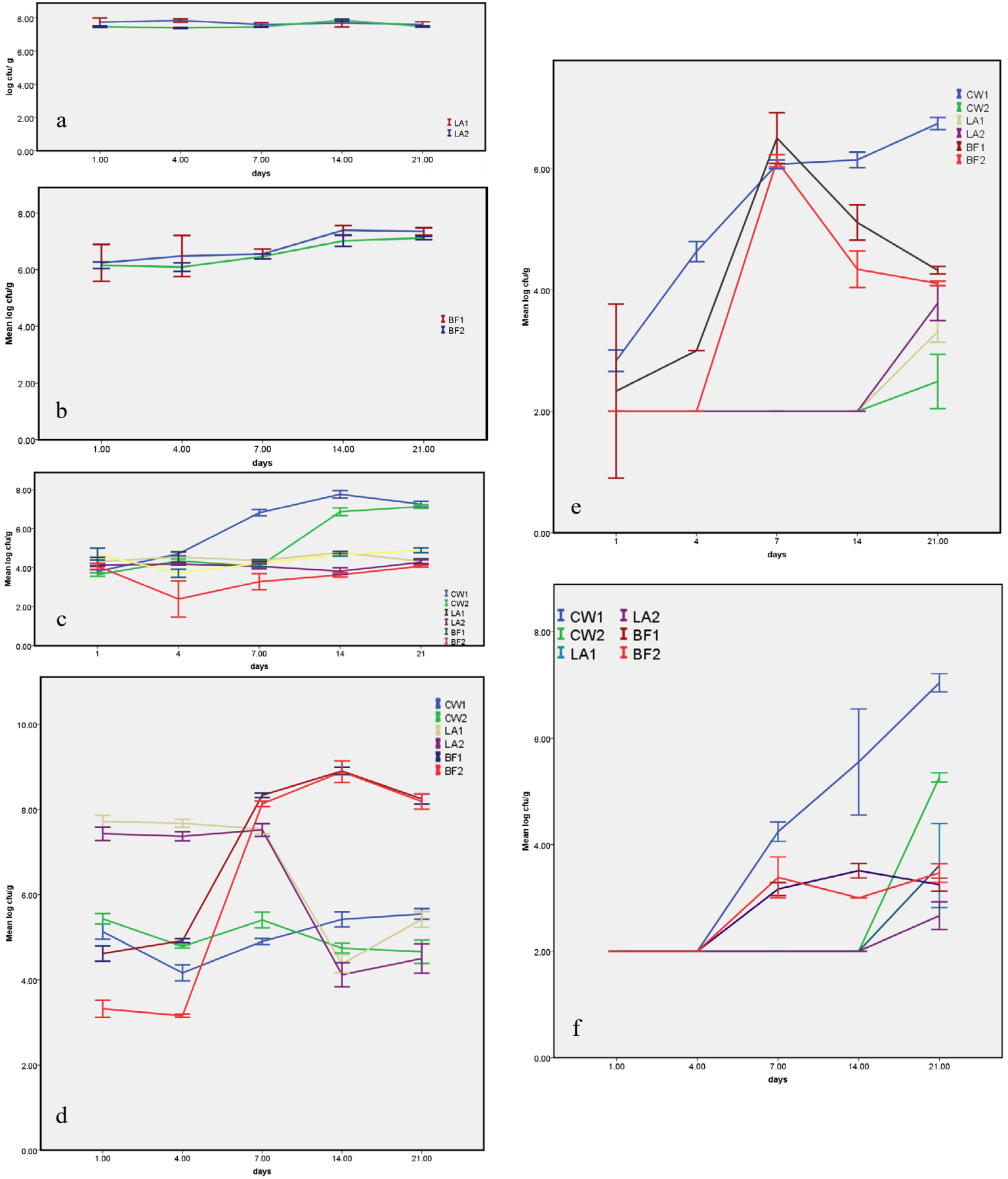

Fig. 1. Growth rates of Lactobacillus acidophilus NRRL B $4495 \log \mathrm{cfu} / \mathrm{g}$ (a), Bifidobacterium bifidum NRRL B41410 log cfu/g (b), total mesophilic bacteria log cfu/g (c), total lactic acid bacteria log cfu/g (d), Pseudomonas spp. $\log \mathrm{cfu} / \mathrm{g}(\mathbf{e})$, yeast numbers $\log \mathrm{cfu} / \mathrm{g}(\mathbf{f})$ in lor samples during storage period $\left(21\right.$ days at $\left.4^{\circ} \mathrm{C}\right)$. Error bars represent the standart deviation of means $(n=3)$. CW1 - lor cheese (control) unsalted, CW2 - lor cheese (control) $1 \%(\mathrm{w} / \mathrm{w})$ salted, LA1 - lor cheese (Lactobacillus acidophilus NRRL B 4495 added) unsalted, LA2 - lor cheese (Lactobacillus acidophilus NRRL B 4495 added) 1\% (w/w) salted, BF1 - lor cheese (Bifidobacterium bifidum NRRL B41410 added) unsalted, BF2 - lor cheese (Bifidobacterium bifidum NRRL B41410 added) 1\% 
these were present at averages of 5.13-5.54 log cfu/g (CW1), 5.43-4.66 log cfu/g (CW2), 7.72-5.42 log $\mathrm{cfu} / \mathrm{g}$ (LA1), 7.43-4.50 log cfu/g (LA2), 4.61-8.24 $\log \mathrm{cfu} / \mathrm{g}(\mathrm{BF} 1), 3.26-8.18 \mathrm{log} \mathrm{cfu} / \mathrm{g}(\mathrm{BF} 2)$ in the lor samples.

Results also showed that the levels of Pseudomonas spp. in CW1 lor samples exceeded $6.74 \mathrm{log} \mathrm{cfu} / \mathrm{g}$ over 21 days storage at $4^{\circ} \mathrm{C}$, and this was significantly $(p<0.05)$ higher than the other groups (Fig. 1e). In LA1 and LA2 samples, the numbers remained constant at $2 \log \mathrm{cfu} / \mathrm{g}$ until the $21^{\text {st }}$ storage day, then increased to $3.31 \mathrm{log} \mathrm{cfu} / \mathrm{g}$ and $3.78 \mathrm{log} \mathrm{cfu} / \mathrm{g}$ respectively. LA1 and LA2 groups contained lower numbers of Pseudomonas spp. than the BF1 and BF2 sample groups.

In all of the samples, the quantity of yeast remained $<5 \log \mathrm{cfu} / \mathrm{g}$, except for the CW1 and CW2 samples; moulds were not observed in any of the lor samples ( $p<0.05$; Fig. 1f). The highest yeast numbers were in the samples CW1 (7.04 log cfu/g), followed by CW2 (5.26 log cfu/g), and the lowest were in LA2 (2.66 log $\mathrm{cfu} / \mathrm{g})$ and BF1 (3.25 log cfu/g) after 21 days' storage. There were significant differences in yeast numbers in $\mathrm{CW} 1, \mathrm{BF} 1$ and BF2 samples on the $7^{\text {th }}$ day $(p<0.05)$.

\section{Sensory properties of lor groups}

The incorporation of probiotic bacteria into lor samples had no significant sensory effects on the $1^{\text {st }}$ day $(p>0.05)$ but there were some significant differences between the groups on subsequent days $(p<0.05$; Table 2). The worst scores for odour and taste were found in the CW1 and CW2 lor samples. The odour of $\mathrm{CW} 1$ and $\mathrm{CW} 2$ was very unpleasant, and the taste was unacceptable after 14 days of storage.

\section{DISCUSSION}

There were no significant differences between the fat, protein and dry matter levels of the different sample groups in our study. Similarly, Madureira et al. (2013) reported that there were no significant differences $(p>0.05)$ in the fat, protein and dry matter levels in cheeses to which Lb. acidophilus and Bf. animalis had been added in their research.

It has been stated that an important factor affecting the survival of probiotic bacterial strains in food is $\mathrm{pH}$; viability is decreased at low $\mathrm{pH}$ values. Hence, whey cheese should be a good vehicle for probiotic strains because it generally has a $\mathrm{pH}$ in the $6.0-6.5$ range, and never lower than 4.5 , even after 28 days of storage (Madureira et al., 2005). In our study the lowest $\mathrm{pH}$ value, 4.86, was obtained in the BF1 group after 21 days of storage.

Madureira et al. (2013) reported $\mathrm{pH}$ values of 6.18-6.95 in control lor samples, 5.99-5.67 in groups with $L b$. acidophilus added and 6.01-5.85 in lor groups with $B f$. animalis added after 21 days of storage. Madureira et al. (2005) also found $\mathrm{pH}$ values of 6.22-5.51 for control lor samples, 6.24-6.95 for samples with added $L b$. acidophilus, and 6.26-6.95 for samples with added $B f$. animalis and $0.8 \%$ salt $(\mathrm{w} / \mathrm{v}$; salt/whey), after 28 days of storage.

Previous studies have reported that the most important factor for a decrease in bacterial viability is decreasing $\mathrm{pH}$ during storage, and the formation of organic acids (Kailasapathy et al., 2008; Shah, 2000). The $\mathrm{pH}$ in probiotic dairy products is generally $3.7-$ 4.3, which is lower than the $\mathrm{pH}$ range of 4.8-5.6 for standard cheeses. But in a cheese matrix, probiotic bacteria can grow more easily, because the $\mathrm{pH}$ is closer to their optimal value (Plessas et al., 2012).

Many studies have shown that probiotics are highly viable in dairy-based products (Buriti et al., 2007; Kailasapathy et al., 2008; Phillips et al., 2006; Rodgers, 2008). Ganesan et al. (2014) reported that starter lactococci, nonstarter lactobacilli and probiotic bacteria are capable of surviving the Cheddar cheese making and ageing process. Miocinovic et al. (2014) found low-fat UF cheese represents a good vehicle for probiotic bacteria, which maintains satisfactory viability throughout the ripening process. The use of probiotic bacteria improves the sensory characteristics of cheeses. A high number of Lb. acidophilus LAFTI RL10, $>10^{7} \mathrm{cfu} / \mathrm{g}$, was found throughout the ripening period; this is necessary for therapeutic effects.

Madureira et al. (2013) demonstrated that numbers of Lb. acidophilus were between 7.86-8.32 log $\mathrm{cfu} / \mathrm{g}$ in whey cheeses during the 21 days of storage. Madureira et al. (2005) determined viable cell numbers of an Lb. acidophilus strain in a control probiotic whey cheese matrix increased by $2.0 \log$ cycles within 28 days of storage; such a trend was not observed for the salt-added matrix $(P<0.05)$, but was found in the sugar-added matrix $(P>0.05)$. 
Irkin, R., Yalcin, O. (2017). The potential use of probiotic strains Lactobacillus acidophilus NRRL B 4495, Bifidobacterium bifidum NRRL B41410 in "Lor Whey Cheese" and the effects on sensory properties. Acta Sci. Pol. Technol. Aliment., 16(2), 181-189. http:// dx.doi.org/10.17306/J.AFS.2017.0493

It was stated that, during the ripening period, the viability of Bifidobacteria (Bf. lactis LAFTI R B94) was maintained at a relatively constant level. A significant reduction in their number was found at the end of the investigated ripening period $\left(<10^{7} \mathrm{cfu} / \mathrm{g}\right)$, probably due to their sensitivity to low $\mathrm{pH}$ values (Miocinovic et al., 2014).

Matias et al. (2014) developed a probiotic soybased product similar to petit-suisse cheese. The viability of $B f$. animalis $\mathrm{Bb}-12$ always remained above $8 \log \mathrm{cfu} / \mathrm{g}$ for all cheese trials during the 28 days of storage at $4^{\circ} \mathrm{C}$. In another study, Madureira et al. (2013) reported that the viability of $B f$. animalis numbers in whey cheese increased to 8.59 from $7.97 \mathrm{log}$ $\mathrm{cfu} / \mathrm{g}$ after 21 days of storage.

Ganesan et al. (2014) explained that survival of bifidobacterial species in even one cheese type may change. The variations in fat levels and physico-chemical conditions inside the cheese matrices can alter the viability of a given strain of bacteria.

Madureira et al. (2005) determined that the type of matrix (i.e. plain or supplemented with sugar or salt) is the most important factor affecting the viability profiles of bacterial strains; control and sugar-supplemented matrices in whey cheeses are better for growth (7.85-8.96 log cfu/g) than the salt-supplemented matrix $(7.38-7.98 \log \mathrm{cfu} / \mathrm{g})$, for example in the case of the $B f$. animalis strain.

The growth-inhibiting effects seen on probiotic culture-supplemented samples may be related to the formation of bacteriocins, lactic and acetic acids, hydrogen peroxide, ethanol, diacetyl, acetaldehyde and acetoin compounds (Fernandes et al., 2013; Matias et al., 2014; Ricciardi et al., 2014).

As a result, it can be said that consumption of a nominal serving $(30 \mathrm{~g})$ of lor cheese per day provides an intake of Lb. acidophilus or Bf. bifidum of $10^{6}-10^{7} \mathrm{cfu} / \mathrm{g}$, which is the optimum level recommended to provide therapeutic benefits (Phillips et al., 2006). Ganesan et al. (2014) explained that, when adjunct or probiotic bacteria are included in the cheese matrix, the balance of LAB populations can be altered because of the competition for nutritional components between the microorganisms.

Madureira et al. (2011) determined that the use of probiotic strains like Bf. animalis or Lactobacillus ca$s e i$ in whey cheeses can make them safer and extend the shelf life, due to the inhibition of Listeria innocua, Salmonella Enteritidis, Staphylococcus aureus and food spoilage microorganisms such as Pseudomonas aeruginosa and Escherichia coli.

Cichosz et al. (2014) found higher counts of mesophilic lactic acid bacteria in experimental ripened cheese than in control cheese, and explained that the addition of L. rhamnosus HN001 to experimental cheeses promoted the viability of starter cultures by inhibiting the growth of harmful microflora, such as the coliform group, yeast and mould, and increased the quantity of easily available substrates.

Minervini et al. (2012) explained that the addition of Bifidobacteria to Gouda and cottage cheeses has a negative effect on the flavour of cheeses, because the concentration of acetic acid was too high and proteolysis too extensive, which decreased consumer acceptability compared to traditional cheeses. In this research LA2, LA1 and BF2 samples had the highest total acceptability scores during storage.

\section{CONCLUSION}

In this work we have shown that lor whey cheese is a good vehicle for probiotic bacteria. Upon inoculation in whey cheeses, Bf. bifidum NRRL B41410 and Lb. acidophilus NRRL B 4495 maintained their viable cell numbers throughout 21 days of storage. No relevant physicochemical changes occurred in terms of fat, protein and moisture content during this period, except for a slight decrease in $\mathrm{pH}$ relative to the control. The sensory evaluation showed that the overall aroma of lor cheeses was improved markedly by the addition of the probiotic cultures $L b$. acidophilus NRRL B 4495. The addition of salt to the lor samples caused growth restrictions for some microorganism groups and also affected the sensory results for lor cheeses.

\section{REFERENCES}

AOAC (1995). Official Methods 948.12, 935.43, 971.19, 955.30. $16^{\text {th }}$ ed. Washington, DC: Association of Official Analytical Chemists.

Buriti, F. C. A., Freitas, S. C., Egito, A. S., Santos, K. M. O. (2014). Effects of tropical fruit pulps and partially hydrolysed galactomannan from Caesalpinia pulcherri$m a$ seeds on the dietary fibre content, probiotic viability, 
Irkin, R., Yalcin, O. (2017). The potential use of probiotic strains Lactobacillus acidophilus NRRL B 4495, Bifidobacterium bifidum NRRL B41410 in "Lor Whey Cheese" and the effects on sensory properties. Acta Sci. Pol. Technol. Aliment., 16(2), 181-189. http:// dx.doi.org/10.17306/J.AFS.2017.0493

texture and sensory features of goat dairy beverages. LWT - Food Sci. Technol., 59, 196-203.

Cichosz, G., Aljewicz, M., Nalepa, B. (2014). Viability of the Lactobacillus rhamnosus HN001 probiotic strain in Swiss- and Dutch-type cheese and cheese-like products. J. Food Sci., 79(6), 1181-1188.

Ciftcioglu, G., Erkan, M. E., Vural, A., Aksu, H. (2008). Assessment of some microbiological and chemical properties of Lor whey cheese. J. Food Agric. Environ., 6(3-4), 109-113.

Fernandes, M. S., Cruz, A. G., Arroyo, D. M. D, Faria, J. A. F., Cristianini, M., Sant'Ana, A. S. (2013). On the behavior of Listeria innocua and Lactobacillus acidophilus co-inoculated in a dairy dessert and the potential impacts on food safety and product's functionality. Food Contr., 34, 331-335.

Freitas, A. C., Rodrigues, D., Sousa, S., Gomes, A. M., Pintado, M. M. (2014). Food as vehicles of probiotics. In S. Ötleş (Ed.), Probiotic bacteria fundamentals. Therapy and technological aspects (pp. 95-169). Singapore.

Ganesan, B., Weimer, B. C., Pinzon, J., Kong, N. D., Rompato, G., Brothersen, C., McMahon, D. J. (2014). Probiotic bacteria survive in Cheddar cheese and modify populations of other lactic acid bacteria. J. Appl. Microbiol., 116, 1642-1656.

Granato, D., Branco G. F., Cruz, A. G., Faria, A. F., Shah, N. P. (2010). Probiotic dairy products as functional foods. Compr. Rev. Food Sci. Food Saf., 9, 455-470.

Gonzales-Fandos, E., Sanz, S., Olarte, C. (2000). Microbiological, physicochemical and sensory characteristics of Cameros cheese packaged under modified atmospheres. Food Microbiol., 17, 407-414.

Hattingh, A. I., Viljoen, B. C. (2001). Yoghurt as a probiotic carrier food. Int. Dairy J., 11, 1-17.

Irkin, R. (2011). Shelf-life of unsalted and light "lor" whey cheese stored under various packaging conditions: microbiological and sensory attributes. J. Food Proces. Preserv., 35, 163-178.

Ishibashi, N., Yamazaki, S. (2001). Probiotics and safety. Am. J. Clin. Nutr., 73, 465-470.

ISO 13720 (2000). Microbiology of food and animal feding stuffs-Horizontal method for enumeration of Pseudomonass spp. Standard.

Kailasapathy, K., Harmstorf, I., Phillips, M. (2008). Survival of Lactobacillus acidophilus and Bifidobacterium animalis ssp. lactis in strirred fruit yogurts. LWT - Food Sci. Technol., 41, 1317-1322.

Krystallis, A., Maglaas, G., Mamalis, S. (2008). Motivations and continue structures of consumers in their purchasing of functional foods. Food Qual. Prefer., 19, 525-538.
Kun, S., Judit, M., Szabo, R., Nguyen, Q. D., Hoschke, A. (2008). Changes of microbial population and some components in carrot juice during fermentation with selected Bifidobacterium strains. Proces. Biochem., 43, 816-821.

Madureira, A. R., Giao, M. S., Pintado, M. E., Gomes, A. M. P., Freitas, A. C., Malcata, F. X. (2005). Incorporation and survival of probiotic bacteria in whey cheese matrices. J. Food Sci., 70(3), 160-165.

Madureira, A. R., Pintado, M. E., Gomes, A. M. P., Malcata, F. X. (2011). Incorporation of probiotic bacteria in whey cheese: decreasing the risk of microbial contamination. J. Food Protec., 6, 1194-1199.

Madureira, A. R., Soares, J. C., Amorim, A., Tavares, T., Gomes, A. M., Pintadoa, M. M., Malcata, F. X. (2013). Bioactivity of probiotic whey cheese: characterization of the content of peptides and organic acids. J. Food Agric. Environ., 93, 1458-1465.

Matias, N. S., Bedani, R., Castro, I. A., Saad, S. M. I. (2014). A probiotic soy-based innovative product as an alternative to petit-suisse cheese. LWT - Food Sci. Technol., 59, 411-417.

Minervini, F., Siragusa, S., Faccia, M., Bello, F. S., Gobetti, M., Angelis, M. D. (2012). Manufacture of Fior di Latte cheese by incorporation of probiotic lactobacilli. J. Dairy Sci., 95, 508-520.

Miocinovic, J., Radulovic, Z., Paunovic, D., Miloradovic, Z., Trpkovic, G., Radovanovic, M., Pudja, P. (2014). Properties of low-fat ultra filtered cheeses produced with probiotic bacteria. Archiv. Biolog. Sci., 66(1), 65-73.

Nagpal, R., Yadav, H., Kumar, M., Jain, S., Yamashiro, Y., Marotta, F. (2014). Probiotics, prebiotics and symbiotics: An introduction. In S. Ötleş (Ed.), Probiotics and prebiotics in food, nutrition and health (pp. 1-25). New York.

Phillips, M., Kailasapathy, K., Tran, L. (2006). Viability of commercial probiotic cultures (L. acidophilus, B. Sp., L. casei, L. paracasei and L. rhamnosus) in cheddar cheese. Int. J. Food Microbiol., 108, 276-280.

Plessas, S., Bosnea, L., Alexopoulos, A., Bezirtzoglou, E. (2012). Potential effects of probiotics in cheese and yoghurt production: A review. Eng. Life Sci., 12(4), 433-440.

Ricciardi, A., Blaiotta, G., Cerbo, A. D., Succi, M., Aponte, M. (2014). Behaviour of lactic acid bacteria populations in Pecorino di Carmasciano cheese samples submitted to environmental conditions prevailing in the gastrointestinal tract: Evaluation by means of a polyphasic approach. Int. J. Food Microbiol., 179, 64-71. 
Irkin, R., Yalcin, O. (2017). The potential use of probiotic strains Lactobacillus acidophilus NRRL B 4495, Bifidobacterium bifidum NRRL B41410 in "Lor Whey Cheese" and the effects on sensory properties. Acta Sci. Pol. Technol. Aliment., 16(2), 181-189. http:// dx.doi.org/10.17306/J.AFS.2017.0493

Rodgers, S. (2008). Novel applications of live bacteria in food services: probiotics and protective cultures. Trends Food Sci. Technol., 19, 188-197.

Shah, N. P. (2000). Probiotic bacteria: selective enumeration and survival in dairy foods. J. Dairy Sci., 83(4), 894-907.

Tamime, A. Y., Saarela, M., Sondergaard, A. K., Mistry, V. V., Shah, N. P. (2005). Production and maintenance of viability of probiotic micro-organisms in dairy products. In A. Tamim (Ed.), Probiotic dairy products (pp. 39-63). Oxford, UK.
Tharmaraj, N., Shah, N. P. (2003). Selective Enumeration of Lactobacillus delbrueckii ssp. bulgaricus, Streptococcus thermophilus, Lactobacillus acidophilus, Bifidobacteria, Lactobacillus casei, Lactobacillus rhamnosus, and Propionibacteria. J. Dairy Sci., 86, 2288-2296.

Urala, N., Lähteenmäki, L. (2007). Consumer's changing attitudes towards functional foods. Food Qual. Prefer., $18,1-12$.

Whitley, E., Muir, D., Waites, W. M. (2000). The growth of Listeria monocytogenes in cheese packed under a modified atmospher. J. Appl. Microbiol., 88, 52-57. 